\title{
Kamil Krauschar"
}

\section{DOPUSZCZALNOŚĆ DOKONYWANIA ZMIAN W BUDŻECIE PRZEZ ZASTĘPCĘ WÓJTA (BURMISTRZA, PREZYDENTA) URZĘDU GMINY (MIASTA) - ANALIZA ROZSTRZYGNIECĆ WOJEWÓDZKICH SĄDÓW ADMINISTRACYJNYCH}

\section{Streszczenie}

W artykule zawarto ogólne zagadnienia dotyczące problematyki dopuszczalności dokonywania zmian w budżecie przez zastępcę wójta (burmistrza, prezydenta) urzędu gminy (miasta). Przedstawiono rozbieżne stanowiska sądów administracyjnych, które opowiadają się za możliwością dokonywania zmian w budżecie przez zastępcę wójta, jak i przedstawią poglądy zupełnie odmienne. W rozważaniach końcowych podniesione zostały postulaty $\mathrm{w}$ zakresie ponownego podjęcia tematyki w przedmiocie uregulowania expressis verbis $\mathrm{w}$ akcie o charakterze ustawowym, tj. rozszerzenia katalogu przypadków związanych z przemijającą przeszkodą w wykonywaniu przez wójta zadań i kompetencji, a także jednoznaczne określenie zagadnienia dotyczącego dokonywania zmian w budżecie jednostki samorządu terytorialnego przez zastępcę wójta.

Słowa kluczowe: budżet, dekoncentracja uprawnień, umocowanie organu wykonawczego

* mgr Kamil Krauschar, prawnik, członek Kolegium Regionalnej Izby Obrachunkowej w Warszawie, członek Regionalnej Komisji Orzekającej w sprawach o naruszenie dyscypliny finansów publicznych przy Regionalnej Izbie Obrachunkowej w Warszawie, adres e-mail: kamil. krauschar@wp.pl. ORCID: 0000-0001-9368-5974 
Podstawą gospodarki finansowej jednostki samorządu terytorialnego w danym roku budżetowym jest uchwała budżetowa ${ }^{1}$. Uchwała budżetowa, a ściślej budżet, stanowi podstawę rocznego planowania dochodów i wydatków oraz przychodów i rozchodów jednostki. Uchwała budżetowa prócz obligatoryjnych elementów zawiera szczególne zasady wykonywania budżetu jednostki samorządu terytorialnego w roku budżetowym, wynikające z odrębnych ustaw ${ }^{2}$. Określa również w swej treści (konstrukcji) przedmiotowej, że organ stanowiący jednostki samorządu terytorialnego może upoważnić zarząd $^{3}$ do dokonywania zmian w budżecie ${ }^{4}$, a ponadto że w toku wykonywania budżetu jednostki samorządu terytorialnego obowiązują zasady gospodarki finansowej, według których dokonywanie wydatków następuje w granicach kwot określonych $\mathrm{w}$ planie finansowym, $\mathrm{z}$ uwzględnieniem prawidłowo dokonanych przeniesień i zgodnie z planowanym przeznaczeniem, w sposób celowy i oszczędny, z zachowaniem zasady uzyskiwania najlepszych efektów z danych nakładów 5 .

Zakres dopuszczalnych zmian w budżecie, a także zakres kompetencji do dokonywania zmian w budżecie ustawodawca zawarł w przepisach art. 257 u.f.p. i art. 258 u.f.p. Zgodnie z art. 257 u.f.p. w toku wykonywania budżetu zarząd może dokonywać zmian w planie dochodów i wydatków budżetu jednostki samorządu terytorialnego polegających na zmianach planu:

a) dochodów i wydatków związanych ze zmianą kwot lub uzyskaniem dotacji przekazywanych z budżetu państwa, $\mathrm{z}$ budżetów innych jednostek samorządu terytorialnego oraz innych jednostek sektora finansów publicznych;

b) dochodów jednostki samorządu terytorialnego, wynikających ze zmian kwot subwencji w wyniku podziału rezerw subwencji ogólnej;

c) wydatków jednostki samorządu terytorialnego w ramach działu w zakresie wydatków bieżących, z wyjątkiem zmian planu wydatków na uposażenia i wynagrodzenia ze stosunku pracy, o ile odrębne przepisy nie stanowią inaczej;

1 Art. 211 ust. 4 ustawy z dnia 27 sierpnia 2009 r. o finansach publicznych (tekst jedn. Dz.U. z 2019 r., poz. 869), dalej jako u.f.p.

2 Art. 212 ust. 1 pkt 8 u.f.p.

3 Przez zarząd jednostki samorządu terytorialnego rozumie się również wójta, burmistrza lub prezydenta miasta (art. 2 pkt 2 u.f.p.).

4 Art. 212 ust. 2 pkt 2 u.f.p.

5 Art. 254 pkt 3 u.f.p. 
d) dochodów i wydatków jednostki samorządu terytorialnego związanych ze zwrotem dotacji otrzymanych z budżetu państwa lub innych jednostek samorządu terytorialnego.

Dodatkowo ustawodawca w zakresie kompetencyjnym, o którym mowa w art. 258 u.f.p., wyraził, że organ stanowiący jednostki samorządu terytorialnego może upoważnić zarząd do:

a) dokonywania innych zmian w planie wydatków niż określone w art. 257 ust. 1 u.f.p., z wyłączeniem przeniesień wydatków między działami;

b) przekazania niektórych uprawnień do dokonywania przeniesień planowanych wydatków innym jednostkom organizacyjnym jednostki samorządu terytorialnego;

c) przekazania uprawnień innym jednostkom organizacyjnym jednostki samorządu terytorialnego do zaciągania zobowiązań z tytułu umów, których realizacja w roku budżetowym i w latach następnych jest niezbędna do zapewnienia ciągłości działania jednostki i z których wynikające płatności wykraczają poza rok budżetowy;

d) dokonywania zmian w planie dochodów i wydatków związanych ze:

- zmianą kwot lub uzyskaniem płatności przekazywanych z budżetu środków europejskich, o ile zmiany te nie pogorszą wyniku budżetu,

- zmianami w realizacji przedsięwzięcia finansowanego $\mathrm{z}$ udziałem środków europejskich albo środków, o których mowa w art. 5 ust. 1 pkt 3 u.f.p., o ile zmiany te nie pogorszą wyniku budżetu,

- zwrotem płatności otrzymanych z budżetu środków europejskich.

W nawiązaniu do powyższych unormowań zasadne jest uzyskanie odpowiedzi na następujące pytania:

1. Czy ustawodawca, na tle obowiązujących uregulowań prawnych, dopuszcza możliwość dokonywania zmian w budżecie przez zastępcę wójta (burmistrza, prezydenta) urzędu gminy (miasta)?

2. Czy kompetencje organu wykonawczego w zakresie zmian w budżecie można scedować na inny podmiot na podstawie art. 33 ust. 4 ustawy z dnia 8 marca 1990 roku o samorządzie gminnym ${ }^{6}$ ?

W przywołanej ustawie zarządowi jednostki samorządu terytorialnego (wójtowi, burmistrzowi, prezydentowi miasta) przypisano wiele czynności związanych z wykonywaniem budżetu danej jednostki, ograniczając się jedynie do

6 Ustawa z dnia 8 marca 1990 r. o samorządzie gminnym (tekst jedn. Dz.U. z 2019 r., poz. 506), dalej jako u.s.g. 
wskazania bezpośrednio adresata normy i sprecyzowania wprost przysługujących mu czynności prawnych. W tym miejscu niezbędną czynnością będzie odniesienie się do uregulowań związanych z wykonywaniem uchwały budżetowej, jakie zostały zawarte w ustawie ustrojowej. W myśl art. 26 ust. 1 u.s.g. organem wykonawczym gminy jest wójt, któremu przypisano wśród katalogu zadań ustawowych m.in. wykonywanie budżetu ${ }^{7}$. Ponadto wójt jest organem administracji i wydaje decyzje w indywidualnych sprawach z zakresu administracji publicznej, a także kieruje bieżącymi sprawami gminy oraz reprezentuje ją na zewnątrz ${ }^{8}$.

W ustawie ustrojowej przewidziano możliwość scedowania przez niego niektórych spraw związanych z działaniem gminy. Artykuł 33 ust. 4 u.s.g. określa, że wójt może powierzyć prowadzenie określonych spraw gminy w swoim imieniu zastępcy wójta lub sekretarzowi gminy. Tym bardziej, że w przypadku przemijającej przeszkody w wykonywaniu zadań i kompetencji wójta spowodowanej jedną z następujących okoliczności: tymczasowym aresztowaniem, odbywaniem kary pozbawienia wolności wymierzonej za przestępstwo nieumyślne, odbywaniem kary aresztu, niezdolnością do pracy z powodu choroby trwającej powyżej 30 dni, zawieszeniem w czynnościach służbowych, jego zadania i kompetencje przejmuje zastępca, a w gminach, w których powołano więcej niż jednego zastępcę - pierwszy zastępca9.

W praktyce pojawiły się wątpliwości dotyczące możliwości dokonywania zmian w budżecie przez zastępcę wójta (burmistrza, prezydenta) urzędu gminy (miasta $)^{10}$. Na podstawie dotychczasowego orzecznictwa sądów administracyjnych wykształciły się odmienne, skrajne stanowiska. Rozstrzygnięcia w spornych sprawach przedstawiły dychotomiczny obraz prawnych możliwości dokonywania zmian w budżecie przez zastępcę wójta urzędu gminy.

Pierwsze stanowisko opowiada się za niemożnością dokonywania zmian w budżecie przez inne podmioty niż wójt (burmistrz, prezydent) ${ }^{11}$. Niemożność upatrywana jest $\mathrm{w}$ braku upoważnienia ustawowego dotyczącego prawnych możli-

7 Art. 30 ust. 2 pkt 4 u.s.g.

8 Art. 31 u.s.g. i art. 39 ust. 1 u.s.g.

9 Art. 28 g ust. 1 u.s.g.

10 A. Skoczylas, w: Ustawa o samorzadzie gminnym. Komentarz z odniesieniami do ustaw o samorzadzie powiatowym i samorządzie województwa, red. R. Hauser, Z. Niewiadomski, Warszawa 2011, s. 398; A. Szewc, w: Ustawa o samorzadzie gminnym. Komentarz, red. A. Szewc, G. Jyż, Z. Pławecki, Warszawa 2012, art. 33, s. 518; A. Wierzbica, w: Ustawa o samorzadzie gminnym. Komentarz, red. B. Dolnicki, Warszawa 2010, s. 567.

11 Wyrok WSA w Poznaniu z dnia 28 października 2015 r., sygn. akt I SA/Po 1300/15, LEX nr 1932515. 
wości ingerowania w strukturę budżetu jednostki samorządu terytorialnego. W uzasadnieniu wyroku WSA w Poznaniu z dnia 28 października 2015 roku podniesiono, że regulacje ustawy o samorządzie gminnym nie przyznają zastępcy wójta żadnych samodzielnych kompetencji. Dysponuje on jedynie uprawnieniami, które wójt zechce mu przydzielić. Istotny pozostaje zatem stan faktyczny konkretnej sprawy, w którym należy poszukiwać zakresu umocowania konkretnego zastępcy. Dalej sąd wskazał, że ustawodawca w ustawie o finansach publicznych nie przewidział możliwości scedowania swoich uprawnień jako organu wykonawczego do dokonywania zmian w budżecie na inne osoby, w tym na swojego zastępcę. Jak wynika ze słowniczka zawartego w art. 2 pkt 2 u.f.p., ilekroć w ustawie jest mowa o zarządzie jednostki samorządu terytorialnego, rozumie się przez to również wójta, burmistrza lub prezydenta. Słowniczek nie wymienia zaś ich zastępców. Takiego uprawnienia również nie można było upatrywać w zastosowaniu delegacji art. $28 \mathrm{~g}$ u.s.g. Przepis ten stanowi, że w przypadku przemijającej przeszkody w wykonywaniu zadań i kompetencji wójta spowodowanej jedną z następujących okoliczności: tymczasowym aresztowaniem, odbywaniem kary pozbawienia wolności wymierzonej za przestępstwo nieumyślne, odbywaniem kary aresztu, niezdolnością do pracy z powodu choroby trwającej powyżej 30 dni, zawieszeniem w czynnościach służbowych, jego zadania i kompetencje przejmuje zastępca, a w gminach, w których powołano więcej niż jednego zastępcę, pierwszy zastępca. Z uwagi na to, że nie zachodziła żadna $\mathrm{z}$ wymienionych okoliczności, nie było podstaw prawnych do dokonywania w toku wykonywania budżetu zmian w planie dochodów i wydatków budżetu jednostki samorządu terytorialnego przez zastępcę prezydenta.

$\mathrm{W}$ podobnym tonie wypowiedział się również WSA w Poznaniu w wyroku z dnia 20 lipca 2016 roku $^{12}$, w pełni podzielając stanowisko zaprezentowane przez WSA w Poznaniu w wyroku z dnia 28 października 2015 roku, sygn. akt I SA/Po 1300/15, w którym stwierdzono kategorycznie, że zastępca burmistrza nie ma kompetencji do dokonywania w toku wykonywania budżetu zmian w planie dochodów i wydatków budżetu jednostki. Następnie WSA oparł swoje stanowisko na orzecznictwie, w którym wskazuje się ponadto, że art. 33 ust. 4 u.s.g. trzeba odczytywać w kontekście art. 33 ust. 3 u.s.g. ${ }^{13}$ dającego burmistrzowi uprawnienia do kierowania urzędem gminy, co oznacza możliwość upoważnienia swojego zastępcy do wykonywania czynności tylko w tym zakresie ${ }^{14}$.

12 Wyrok WSA w Poznaniu z dnia 20 lipca 2016 r., sygn. akt III SA/Po 419/16, LEX nr 2087522.

13 Kierownikiem urzędu jest wójt.

14 Wyrok WSA we Wrocławiu z dnia 30 listopada 2012 r., sygn. akt III SA/Wa 487/12, CBOSA. 
Drugie, odmienne stanowisko sprowadza się do wyrażenia aprobaty dokonywania zmian w budżecie przez zastępcę wójta gminy. W wyroku WSA w Poznaniu $\mathrm{z}$ dnia 5 listopada 2015 roku $^{15}$, którego przedmiotem rozstrzygnięcia sprawy była kontrola sądowa możliwości upoważnienia przez wójta gminy swojego zastępcy do podpisania z upoważnienia wójta zarządzenia wójta gminy w sprawie dokonania zmian w planie wydatków ustalonych uchwałą budżetową na rok 2015. Nadmienić należy, że w sprawie bezsporne było, że zastępca wójta gminy był upoważniony, na podstawie pisemnego pełnomocnictwa, do prowadzenia w czasie nieobecności wójta spraw gminy, z wyłączeniem zatrudnienia i zwalniania pracowników urzędu gminy oraz kierowników gminnych jednostek organizacyjnych. Jako podstawę prawną pełnomocnictwa powołano, obowiązujący w dacie jego sporządzenia, przepis art. 33 ust. 4 u.s.g. Wojewódzki Sąd Administracyjny odnosząc się do zarysowanego zagadnienia, stwierdził, że w doktrynie przedmiotu wskazuje się, że do kategorii spraw przekazanych na podstawie art. 33 ust. 4 u.s.g. będą zaliczać się wszystkie zadania publiczne gminy zastrzeżone wyraźnym przepisem prawa do kompetencji wójta. Przekazane sprawy nie muszą zatem ograniczać się tylko do kwestii związanych z funkcjonowaniem urzędu gminy, gdyż przepis stanowi szeroko o sprawach gminy. Powierzenie prowadzenia określonych spraw gminy zastępcy wójta czy sekretarzowi nie zmieni faktu, że wyłącznie odpowiedzialny za realizację tych spraw będzie wójt, pomimo że to nie on będzie ich faktycznym wykonawcą. Świadczy o tym występujący w art. 33 ust. 4 u.s.g. zwrot „w swoim imieniu"16. Sąd rozważając sporne kwestie, wywiódł, że dokonanie zmian w planie wydatków ustalonych uchwałą budżetową na dany rok jest zadaniem zastrzeżonym do kompetencji wójta na mocy szczególnego przepisu ustawy. Ponadto nie było zatem przeszkód, by w ramach dekoncentracji zadań wydane w tym zakresie zarządzenie zostało podpisane przez zastępcę wójta $\mathrm{w}$ ramach udzielonego mu pełnomocnictwa na podstawie art. 33 ust. 4 u.s.g.

Wielokrotnie stanowiska dotyczące możliwości powierzenia kompetencji zastępcy wójta zajmował również NSA m.in. w wyrokach z dnia 24 października 2013 roku, z dnia 31 sierpnia 2012 roku, jak i z dnia 14 listopada 2017 roku czy też z dnia 15 marca 2019 roku. W wyroku z dnia 24 października 2013 roku NSA ${ }^{17}$

15 Wyrok WSA w Poznaniu z dnia 5 listopada 2015 r., sygn. akt I SA/Po 1753/15, LEX nr 1932546.

16 C. Martysz, A.M. Wierzbica, Komentarz do art. 33 ustawy o samorzadzie gminnym, LEX Wydawnictwo elektroniczne.

17 Wyrok NSA z dnia 24 października 2013 r., sygn. akt II OSK 1196/12, LEX nr 1613184. 
wskazał, że ustawa ustrojowa nie przewiduje własnych kompetencji dla zastępcy wójta, lecz zakres jego możliwości działania w imieniu wójta jest określany przez wójta zgodnie z art. 33 ust. 4 u.s.g. Jest to przykład tzw. dekoncentracji wewnętrznej, polegającej na powierzeniu kompetencji wójta w drodze czynności indywidualnej innym podmiotom, tj. jego zastępcy lub sekretarzowi gminy. W myśl art. 33 ust. 4 u.s.g. wójt może powierzyć prowadzenie określonych spraw gminy w swoim imieniu zastępcy wójta lub sekretarzowi gminy. Przepis ten nie wskazuje przy tym ani zakresu, ani rodzaju spraw gminy, które mogą być delegowane na zastępcę wójta lub sekretarza gminy, nie zastrzega też żadnych spraw do wyłącznej kompetencji wójta (w powołanym przepisie mowa jest o określonych, a nie niektórych tylko kompetencjach wójta). Powierzenia określonych kompetencji wójt może dokonać $\mathrm{w}$ zakresie swojej właściwości $\mathrm{w}$ regulaminie organizacyjnym ${ }^{18}$, zakresie czynności lub odrębnym upoważnieniem ${ }^{19}$.

Z kolei w wyroku z dnia 31 sierpnia 2012 roku NSA przyjął, że możliwość powierzenia zadań wójta, które przysługują mu jako kierownikowi urzędu, innej osobie, została przewidziana w art. 33 ust. 4 u.s.g. Zgodnie z tym przepisem wójt może powierzyć prowadzenie określonych spraw gminy w swoim imieniu zastępcy wójta lub sekretarzowi gminy. Ustęp 4 art. 33 u.s.g. uprawniający do delegowania kompetencji wójta na inne ściśle określone podmioty należy odczytywać w kontekście ust. 3. Należy zatem uznać, że art. 33 ust. 4 u.s.g. stanowi o możliwości przeniesienia na zastępcę burmistrza lub sekretarza zadań z zakresu kierowania urzędem. Przepis ten stanowczo wskazuje na ograniczenia podmiotowe, bowiem osobami, które mogą wykonywać funkcje wymienione w art. 33 ust. 4 u.s.g., są włącznie zastępcy (zastępca) wójta lub sekretarz. Stanowisko to znajduje dodatkowo potwierdzenie w art. 5 u.p.s. stanowiącym, że kierownik urzędu może upoważnić sekretarza do wykonywania w jego imieniu zadań $^{20}$, w szczególności z zakresu zapewnienia właściwej organizacji pracy urzędu oraz realizowania polityki zarządzania zasobami ludzkimi ${ }^{21}$.

18 por. Z. Leoński, Nauka administracji, Warszawa 2004, s. 58 i n.

19 por. A. Skoczylas, w: Ustawa o samorządzie gminnym. Komentarz..., s. 398; wyrok NSA z dnia 3 grudnia 2008 r., sygn. akt II OSK 1458/08, orzeczenia.nsa.gov.pl.

20 G. Bieniek, W sprawie reprezentacji gminy jako osoby prawnej, „Rejent” 2003, nr 2, s. 21.

21 E. Klat-Górska, L. Klat-Wertelecka, Upoważnienia udzielane przez organy gminy (zagadnienia wybrane), „Nowe Zeszyty Samorządowe - Opinie Prawne” 2009, nr 3 (poz. 39) - ,upoważnienie do wykonywania w imieniu organu wykonawczego gminy zadań, w szczególności z zakresu zapewnienia właściwej organizacji pracy urzędu oraz realizowania polityki zarządzania zasobami ludzkimi, nie wynika z faktu powołania danej osoby na stanowisko Sekretarza Gminy. Źródłem tego upoważnienia może być wyłącznie oświadczenie organu wykonawczego gminy”. 
Naczelny Sąd Administracyjny w wyrokach z 14 listopada 2017 roku i 15 marca 2019 roku zaakcentował ${ }^{22}$, że przepis art. 33 ust. 4 u.s.g. nie jest podstawą prawną do powierzenia zastępcy wójta podpisania zarządzenia wójta w sprawie zmian w uchwale budżetowej, mimo że zastępca wójta miał upoważnienie wójta do prowadzenia w czasie nieobecności wójta spraw gminy, z wyłączeniem zatrudniania i zwalniania pracowników urzędu oraz kierowników gminnych jednostek organizacyjnych ${ }^{23}$. Dekoncentracja zadań wójta jest nierozłącznie związana z tym, w jakiej roli występuje wójt, czy występuje jako kierownik urzędu, czy jako organ wykonawczy gminy. Zakres zadań i obowiązków w ramach tych funkcji nie jest tożsamy. Przepis zezwalający wójtowi na powierzenie prowadzenia określonych spraw gminy w swoim imieniu zastępcy wójta został umieszczony po ustanawiającym wójta kierownikiem urzędu. Wykładnia językowa przepisu art. 33 ust. 4 u.s.g. nie może być oderwana od treści całego przepisu art. 33, a w szczególności ust. 3 art. 33 u.s.g. Wykładnia ta daje podstawę do stwierdzenia, że wójt może powierzyć zastępcy wójta w swoim imieniu określone sprawy gminy związane z kierowaniem i organizacją urzędem, sprawami pracowniczymi, a nie sprawy dotyczące wójta jako organu wykonawczego gminy. Zatem powierzenie określonych spraw zastępcy wójta należy rozumieć w kontekście uprawnień do kierowania urzędem, a nie w kontekście wypełniania funkcji organu wykonawczego.

Analizując zakres przedmiotowej sprawy w zakresie prawnej możliwości przekazywania uprawnienia do zmian w budżecie przez zastępcę wójta, dostrzegając przy tym odmienną argumentację w orzecznictwie sądów administracyjnych, można stwierdzić, że uzasadnione jest podjęcie przez ustawodawcę prac legislacyjnych, które wyeliminowałyby dostrzeżone skrajne stanowiska sądowe. Opinie dotyczące braku upoważnienia ustawowego do możliwości dokonywania w toku wykonywania budżetu zmian w planie dochodów i wydatków budżetu jednostki samorządu terytorialnego przez zastępcę wójta nie ma charakteru jednostkowego. Zagadnienia poruszane były również przez inne sądy administracyjne, m.in. w wyrokach WSA w Poznaniu z 31 stycznia 2018 roku ${ }^{24}$ czy WSA w Poznaniu z 25 stycznia 2018 roku ${ }^{25}$.

22 Wyrok NSA z dnia 14 listopada 2017 r., sygn. akt II GSK 273/16, LEX nr 2424765; wyrok NSA z dnia 15 marca 2019 r., sygn. akt I GSK 1072/18, LEX nr 2655972.

23 por. A. Piskorz-Ryń, Oceny pracowników samorzadowych, w: Stosunki pracy pracowników samorząowych, red. M. Stec, Warszawa 2008, s. 15 i n.

24 Wyrok WSA w Poznaniu z dnia 31 stycznia 2018 r., sygn. akt III SA/Po 910/17, LEX nr 2441209; wyrok WSA w Poznaniu z dnia 31 stycznia 2018 r., sygn. akt III SA/Po 911/17, LEX nr 2441210.

25 Wyrok WSA w Poznaniu z dnia 25 stycznia 2018 r., sygn. akt III SA/Po 912/17, LEX nr 2443787; wyrok WSA w Poznaniu z dnia 25 stycznia 2018 r., sygn. akt III SA/Po 913/17, LEX nr 2443788. 
Przeprowadzona analiza rozstrzygnięć wojewódzkich sądów administracyjnych na tle obowiązujących regulowań prawnych w zakresie dopuszczalności dokonywania zmian w budżecie przez zastępcę wójta (burmistrza, prezydenta) urzędu gminy (miasta) potwierdza zasadność oraz celowość podjęcia przez ustawodawcę stosownych zmian, zarówno w ustawie z dnia 8 marca 1990 roku o samorządzie gminnym oraz w ustawie z dnia 27 sierpnia 2009 roku o finansach publicznych. Doprecyzowanie przesłanek umożliwiających sytuacje dokonywania zmian w budżecie gminy przez zastępcę wójta wynika przede wszystkim ze „zmieniającej się rzeczywistości - z jednej strony rozwoju społeczeństwa obywatelskiego oraz kapitału społecznego, a z drugiej - rosnącej złożoności funkcjonowania systemu samorządowego, w szczególności uwarunkowań prawnych związanych w wydatkowaniem środków publicznych, niektóre regulacje odnoszące się do jednostek (...) stały się reliktem lub pozostają martwą literą"26.

W ramach nowelizacji prawa powszechnie obowiązującego powinno podjąć się czynności zmierzające do uwypuklenia dodatkowych przeszkód w wypełnianiu przez wójta zadań i kompetencji, ich znaczenia i roli, jaką odgrywają $\mathrm{w}$ ustroju samorządu terytorialnego, poprzez rozszerzenie przesłanek w przedmiocie podjęcia czynności legislacyjnych polegających na rozszerzeniu katalogu okoliczności, o którym mowa w art. 28g ust. 1 u.s.g., polegającym na uzupełnieniu przypadków związanych z przemijającą przeszkodą w wykonywaniu przez wójta zadań i kompetencji, a w konsekwencji dodanie do ust. 1 art. 28g u.s.g. następujących jednostek redakcyjnych:

- pkt 6) urlopu wypoczynkowego,

- pkt 7) z innych przyczyn usprawiedliwiających nieobecność, określonych na podstawie odrębnych przepisów ${ }^{27}$.

Dodatkowo wymagane jest jednoznaczne określenie w przepisach ustawy z dnia 27 sierpnia 2009 roku o finansach publicznych rozwiązania prawnego dotyczącego dokonywania zmian w budżecie jednostki samorządu terytorialnego przez zastępcę wójta. Wyraźne uregulowanie w ustawie powinno być uzewnętrznione przez dodanie art. 257a w ustawie z dnia 27 sierpnia 2009 roku o finansach publicznych, w następującym brzmieniu: W gminie wójt, burmistrz, prezydent może upoważnić do dokonywania zmian w planie dochodów i wydatków budżetu

26 Projekt ustawy o zmianie ustawy o samorządzie gminnym oraz niektórych innych ustaw (druk sejmowy nr 3320 z dnia 11 marca 2019 r.).

27 Chodzi m.in. o sytuacje, o których mowa w rozporządzeniu Ministra Pracy i Polityki Socjalnej z dnia 15 maja 1996 r. w sprawie sposobu usprawiedliwiania nieobecności w pracy oraz udzielania pracownikom zwolnień od pracy (Dz.U. z 2014 r., poz. 1632), np. urlopy okolicznościowe. 
jednostek samorządu terytorialnego, o których mowa w art. 257 - zastępcę wójta lub pierwszego zastępcę wójta, w sytuacjach, o których mowa w art. 28 g ust. 1 ustawy z dnia 8 marca 1990 r. o samorządzie gminnym.

Oczekiwane, jak również postulowane jest także wyraźne określenie przez ustawodawcę korelacji pomiędzy wskazanymi powyżej ustawami, w kształcie przedstawionym powyżej. Takie unormowania wyeliminowały niejasności, rozdźwięk pomiędzy przepisami kształtującymi kwestie gospodarki finansowej prowadzonej na podstawie i w granicach uchwały budżetowej, ale przede wszystkim $\mathrm{z}$ bieżącego, praktycznego funkcjonowania jednostek samorządu terytorialnego.

\section{Literatura}

Bieniek G., W sprawie reprezentacji gminy jako osoby prawnej, „Rejent” 2003, nr 2.

Klat-Górska E., Klat-Wertelecka L., Upoważnienia udzielane przez organy gminy (zagadnienia wybrane), „Nowe Zeszyty Samorządowe - Opinie Prawne” 2003, nr 3.

Leoński Z., Nauka administracji, Warszawa 2004.

Martysz C., Wierzbica A.M., Komentarz do art. 33 ustawy o samorzadzie gminnym, LEX Wydawnictwo elektroniczne.

Piskorz-Ryń A., Oceny pracowników samorządowych, w: Stosunki pracy pracowników samorzadowych, red. M. Stec, Warszawa 2008.

Skoczylas A., w: Ustawa o samorzadzie gminnym. Komentarz z odniesieniami do ustaw o samorzadzie powiatowym i samorzadzie województwa, red. R. Hauser, Z. Niewiadomski, Warszawa 2011.

Szewc A., w: Ustawa o samorzadzie gminnym. Komentarz, red. A. Szewc, G. Jyż, Z. Pławecki, Warszawa 2012.

Wierzbica A., w: Ustawa o samorzadzie gminnym. Komentarz, red. B. Dolnicki, Warszawa 2010.

\section{Akty prawne}

Projekt ustawy o zmianie ustawy o samorządzie gminnym oraz niektórych innych ustaw (druk sejmowy nr 3320 z dnia 11 marca 2019 r.).

Rozporządzenie Ministra Pracy i Polityki Socjalnej z dnia 15 maja 1996 r. w sprawie sposobu usprawiedliwiania nieobecności w pracy oraz udzielania pracownikom zwolnień od pracy (Dz.U. z 2014 r., poz. 1632).

Ustawa z dnia 27 sierpnia 2009 r. o finansach publicznych (tekst jedn. Dz.U. z 2019 r., poz. 869). 
Ustawa z dnia 8 marca 1990 r. o samorządzie gminnym (tekst jedn. Dz.U. z 2019 r., poz. 506 z późn. zm.).

\section{Orzecznictwo}

Wyrok NSA z dnia 15 marca 2019 r., sygn. akt I GSK 1072/18, LEX nr 2655972.

Wyrok NSA z dnia 14 listopada 2017 r., sygn. akt II GSK 273/16, LEX nr 2424765.

Wyrok NSA z dnia 24 października 2013 r., sygn. akt II OSK 1196/12, LEX nr 1613184.

Wyrok NSA z dnia 3 grudnia 2008 r., sygn. akt II OSK 1458/08, orzeczenia.nsa.gov.pl.

Wyrok WSA w Poznaniu z dnia 25 stycznia 2018 r., sygn. akt III SA/Po 912/17, LEX nr 2443787.

Wyrok WSA w Poznaniu z dnia 25 stycznia 2018 r., sygn. akt III SA/Po 913/17, LEX nr 2443788.

Wyrok WSA w Poznaniu z dnia 31 stycznia 2018 r., sygn. akt III SA/Po 910/17, LEX nr 2441209.

Wyrok WSA w Poznaniu z dnia 31 stycznia 2018 r., sygn. akt III SA/Po 911/17, LEX nr 2441210.

Wyrok WSA w Poznaniu z dnia 20 lipca 2016 r., sygn. akt III SA/Po 419/16, LEX nr 2087522.

Wyrok WSA w Poznaniu z dnia 5 listopada 2015 r., sygn. akt I SA/Po 1753/15, LEX nr 1932546.

Wyrok WSA w Poznaniu z dnia 28 października 2015 r., sygn. akt I SA/Po 1300/15, LEX nr 1932515.

Wyrok WSA we Wrocławiu z dnia 30 listopada 2012 r., sygn. akt III SA/Wa 487/12, CBOSA.

\section{ISSUES OF ADMISSIBILITY OF MAKING CHANGES IN THE BUDGET BY THE DEPUTY MAYOR (MAYOR, PRESIDENT) OF THE COMMUNE (CITY) OFFICE}

\section{Summary}

The abstract contains general issues regarding the admissibility of making budget changes by the deputy head of the commune head (mayor, president) of the commune (city) office. Divergent positions of administrative courts have been presented, both of 
which are in favor of the possibility of making changes to the budget by the deputy of the commune head, as well as presenting completely different views. In the final considerations, the postulates regarding the resumption of subject matter in the subject of expressis verbis in a statutory act, i.e. the priority of the Public Finance Act over constitutional laws, the extension of the list of cases related to the transient obstacle in the performance of tasks and competences by the head of the commune also an unambiguous definition of the issue regarding making changes in the budget of the local government unit by the deputy of the commune head.

Keywords: budget, deconcentration of rights, authority of the executive body 